\title{
To boost breast cancer research, a center banks on healthy tissue
}

As the sun rose one Saturday morning last summer, 45 Hispanic women climbed aboard a bus in Evansville, Indiana, each with a nametag and pink satin flower pinned to her shirt. Many of the women worked weekends and had taken the day off to make the fourhour trip to Indianapolis, recalls oncologist Anna Maria Storniolo. Some were young, in tank tops and heels; others were older, with gray hair and glasses. But they all shared one intention: to donate a piece of their breast tissue to science.

Storniolo codirects the Susan G. Komen for the Cure Tissue Bank at Indiana University, where the volunteers were headed. The tissue bank is a first-of-its-kind repository of frozen breast tissue, blood, serum and plasma from healthy women. Established in 2005, it provides researchers with tumor-free specimens to use as control samples in breast cancer studies and to study the characteristics of normal breast tissue.

Despite a demonstrated need for such samples, few scientists believed that women would voluntarily donate their breast tissue or that institutional review boards would approve the procedure. But these challenges did not materialize - in 2005, more than 750 healthy women flocked to a blood collection booth at a charity event in Indianapolis, and the vast majority agreed to have their blood used for future unspecified breast cancer research. Given the strong response, the tissue bank was formally established at the university's Melvin and Bren Simon Cancer Center, and the institute's review board approved the collection of breast tissue.

In November, when the US Preventive Services Task Force put forth controversial recommendations to lower the frequency of mammograms, it did so in part to lower the number of unnecessary breast biopsies. Yet the response to the tissue bank launch in Indiana suggests that many healthy women are willing to assume the risks of an invasive needle biopsy to donate their cells to science. Since the launch of the tissue bank, more than 800 women have donated breast tissue, and another 490 are on a waiting list. Healthy tissue samples "are critical for high quality and meaningful research," says Alison Allan, an oncologist at the London Health Sciences Centre in Ontario, Canada, who is not affiliated with the tissue bank.

The donation process lasts about an hour, with most of that time devoted to paperwork; the breast biopsy itself takes only moments. Using local anesthesia and a hollow needle, surgeons extract a gram of tissue-about the size of two peas. The procedure is not pain free; women typically experience bleeding and bruising, have a temporary scar about one to two millimeters long and run the risk of infection.

Elizabeth Thompson, vice president of health sciences at the Dallas-based Susan G. Komen for the Cure foundation, which partially funds the tissue bank, has been amazed by the willingness of healthy volunteers. "You tell women they can give a part of themselves to research and that there will be a little pain, and they say, 'Okay, when and where? And I'll bring a friend!’” she says.

The Hispanic women who made the trek to Indianapolis were invited as part of an effort to expand the demographics of the tissue bank, which is finally starting to distribute samples. Since the beginning of last year, it has fulfilled ten requests for tissues, with several more applications under review. One of those requesters is Mitch Dowsett from the Institute of Cancer Research in London, who is planning to use the healthy tissue to investigate whether genetic changes in the gene encoding estrogen receptor alpha (ESR1) influence the risk of developing tumors. "Many of our findings in breast cancer studies require comparison with normal tissues to understand their significance," says Dowsett. As such, he says, the tissue bank is "an extraordinarily valuable resource."

Megan Scudellari, Durham, North Carolina

\section{Embryonic stem cell lines given the go-ahead}

Nine months after US President Barack Obama issued an executive order lifting restrictions on human embryonic stem cell (hESC) research in the United States, scientists can at last start to use taxpayer dollars to study newly added cell lines. In the first two weeks of December, National Institutes of Health (NIH) director Francis Collins approved no fewer than 40 new hESC lines for federal funding, although some carry caveats.

The earliest cells to get a green light from Collins included 11 lines from George Daley's lab at Children's Hospital Boston and two lines from Ali Brivanlou of Rockefeller University in New York. These were deemed to meet the agency's informed consent guidelines, established in July.

"Now, with the federal sources of support, it gives us much more flexibility and many more resources to answer broader questions that we weren't even approaching before," says Daley.

Reviewers determined that the remaining 27 lines - part of a single submission by Douglas Melton of Harvard University in Cambridge, Massachusetts-met the ethical spirit of the guidelines despite the fact that a randomization technique prevented researchers from matching consent forms to specific donors.

The NIH Advisory Committee to the Director added a proviso that the use of the 27 stem cell lines should be restricted to projects in line with the wording of the informed consent form, which stipulated that the cells be used to study diabetes-related pancreatic cells. Collins, who has the final say, assented to his committee's recommendations.

Robert Streiffer, a bioethicist at the University of Wisconsin-Madison, commended this decision. "The right answer is to insist on informed consent," he says. "Scientists and people in oversight positions routinely underestimate how important it is to patients and donors that they know at least in broad terms what's happening to the biological samples that they're donating."

With 40 cell lines added to the NIH registry, 31 grants totaling $\$ 21$ million that had been funded last year but put on hold pending the agency's review can now go ahead. As Nature Medicine went to press, an additional 85 cell lines had been submitted for review, and 242 more filings had been requested but not yet completed. None of the cell lines eligible for federal funding under former President George W. Bush have yet been approved.

Elie Dolgin, New York 